\author{
Ye. Hrabovskyi
}

Simon Kuznets Kharkiv National University of Economics, Kharkiv

\title{
METHODS OF CREATING A MULTIMEDIA ONLINE GALLERY
}

The aim of the article is to develop a methodology for creating a multimedia online gallery based on the use of appropriate CMS and key ergonomic requirements. The practical result of the study is a set of recommendations to developers and designers to improve the quality and efficiency of creating a multimedia online gallery. The working hypothesis of the study was the statement that the structure of sections of a multimedia online gallery can be determined on the basis of the necessary functionality of the gallery. To test the working hypothesis of the study, such scientific tasks were achieved to achieve goals as algorithmization of the choice of the structure of a multimedia online gallery, coordination of the basic set of functions, classification of functions and sections by clustering. A tree of goals for the development of a multimedia online gallery has been created in the work. A set of general requirements for the online gallery site, describing conceptual, constructive and other requirements, is considered. The general structure of sections and subsections of the multimedia online gallery is given and substantiated. The software methods of creating an online gallery site are analyzed in detail. The article systematizes the main content management systems and online designers, which allow you to "assemble" the site of the electronic gallery and place it on the Internet from a ready-made standard set of modules and components. Particular attention in the work is paid to the stages of coordination of the technical task and structuring of information. Emphasis is placed on the issues of search engine optimization of the gallery site in order to increase indexing in the relevant systems. The paper presents a clear division of functions of the media gallery project manager and web designer in relation to the development of the gallery site and its promotion in search engines. The article describes the necessary initial data for the development of a multimedia online gallery, which includes the requirements for the developed system, a description of the subject area, resources and time for implementation. The study lists the key stages of creating a multimedia online gallery and analyzes the main components of these stages. The article recommends a description and visualization of the components of a multimedia online gallery involved in the software implementation of the development, in accordance with the proposed general structure of sections and subsections of the online gallery site. As a further direction of this study, it is proposed to consider the creation of a methodology for evaluating the effectiveness of the development of a multimedia online gallery.

Keywords: online gallery, visualization, design, target audience, ergonomic requirements.

\section{Introduction}

Formulation of the problem. In the era of multimedia, educational institutions and museums are increasingly using modern technologies and technical means for educational activities and cultural and educational work. Thanks to new information technologies, virtual museums, websites and mobile applications allow to expand the audience and promote art and culture, especially among schoolchildren and young people. In order to interest the user, the information must be presented in an interactive form. Today, most museums are limited to a business card website that does not meet user requests. It is necessary to create a multimedia resource that meets the modern requirements of visitors. The online multimedia gallery serves as such a multimedia resource with bright visual components. In accordance with the practical significance of the development of a multimedia online gallery as a holistic set of visualized means of presenting information in electronic form, there is a scientific task of creating an appropriate methodology that clearly regulates the order and content of the main elements of the gallery design process.

The analysis of recent researches and publications. The papers [1-5] describe web-based methods and tools for creating virtual objects. The research [6-9] is devoted to the analysis of programming issues of the online component of visual developments. The key aspects of the analysis of the quality of the visual elements of the online gallery are reflected in the works [10-11]. The research [12-14] offers methodological approaches to the development of visualization of the components of multimedia online galleries.

However, modern specialized literature on the visualization of information does not contain a scientifically sound method of developing a multimedia online gallery.

The aim of the article - development of a methodology for creating a multimedia online gallery based on the use of appropriate CMS and key ergonomic requirements. 


\section{Statement of basic materials}

In the museum environment of electronic products are formed a fairly wide and diverse range of products. These are sites, electronic catalogs of museum expositions and collections, photo and video galleries.

The online gallery must meet the requirements of ergonomics, adaptability, the ability to provide users with reference information and other features. However, as the database of works placed in the gallery increases, the amount of information increases and the process of its structuring becomes more complicated, which in turn complicates the process of finding and interacting with the site.

Thus, we can assume that the process of developing a multimedia online gallery can be optimized, taking into account the specifics of the subject area of the content.
Hence, the working hypothesis of the study can be formulated as follows: the structure of the sections of the multimedia online gallery can be determined on the basis of the necessary functionality of the gallery.

To test this hypothesis, the following scientific objectives are achieved:

1) algorithmization of the choice of the structure of the multimedia online gallery;

2) coordination of the basic set of functions;

3) classification of functions and sections by clustering.

In fig. 1 shows a tree of goals to solve the problem. The end result of the research is the development of a multimedia online gallery, the first level of the hierarchy corresponds to the subject of research.

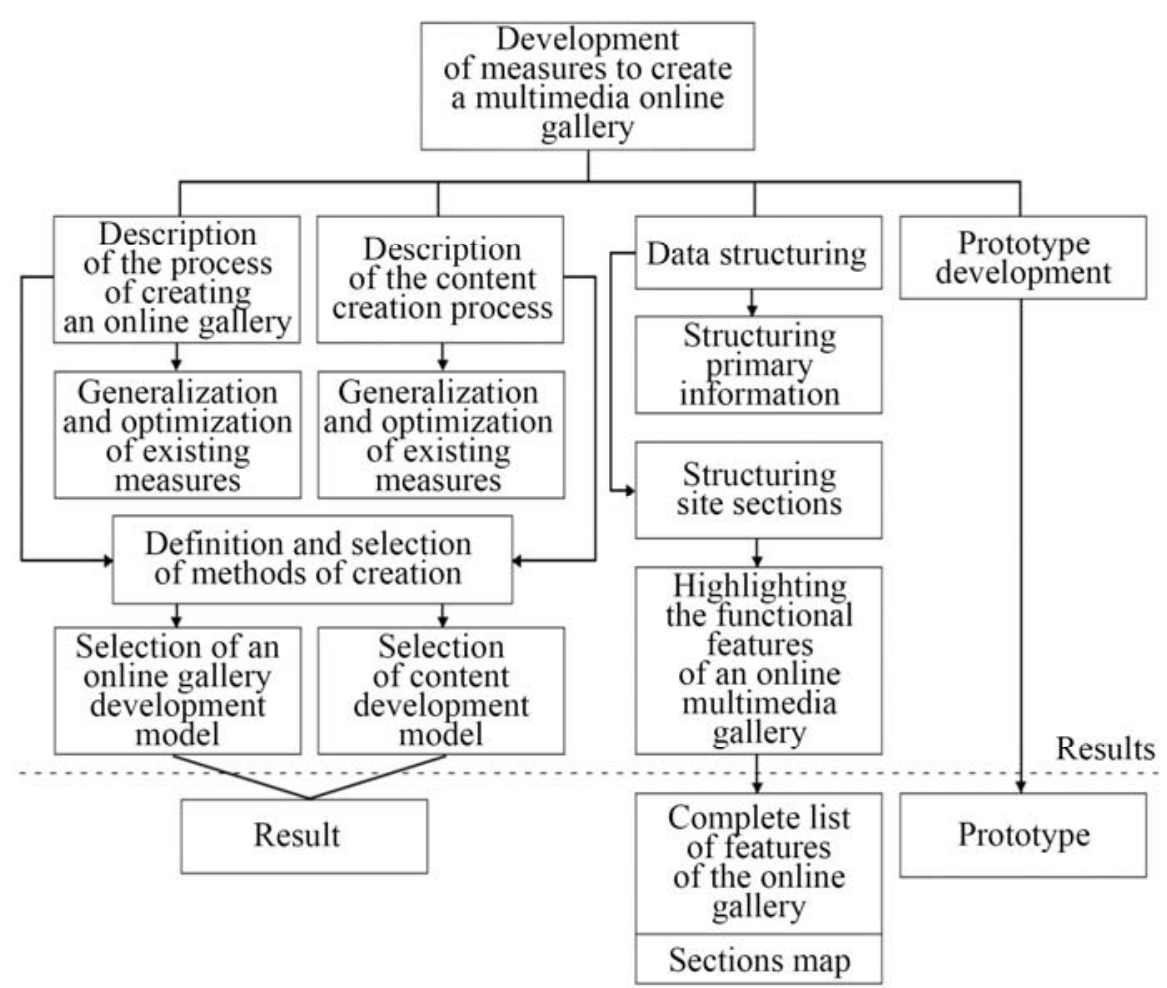

Fig. 1. The tree of goals for the development of a multimedia online gallery Source: author's development.

The formed goals and results of the research allow to neglect the process of achieving the goals as unknown methods and to predict the data that will be obtained at the end of the research.

Before starting to develop a multimedia gallery, taking into account the functional features, it is necessary to consider a set of general requirements for the site of the online gallery, describing the conceptual, constructive and other requirements:

1. Depth of content;

2. Ease of navigation;

3. Accessibility for users;

4. Efficiency of information update;
5. Stability of information resources;

6. Unity of design of all sections.

The depth of the content can be determined by the volume, level of detail and value of the available information. Posting materials of the greatest interest to visitors can increase the informativeness of the site and attract potential users.

Ease of navigation depends on the logic of the hierarchical structure of the site structure. Users need to be able to easily navigate between sections, go back and find the information they need. To achieve this, it is important to remember that the title page must contain a general list of sections of the site. 
The accessibility of the site's pages depends primarily on technical stability, but the design of the pages also plays a very important role. Abuse of illustrative and other materials, for example, can reduce the speed of data transfer and thus significantly complicate the use of the site.

The efficiency of data update provides support for the current state of the site. To ensure the preservation of interest in the site from regular visitors and increase its popularity, it is recommended to conduct regular updates.

The stability of the information content is ensured by the consistency of the presented information. Visitors should be able to easily find the information they need in any technical and structural reorganization. Materials that have lost their relevance should be moved to the archival part of the site in order to provide easy and fast user access to relevant information when visiting the site for the first time.

The appearance of the pages also matters. The main requirement is the same design style of all pages and elements of the site. You also need to pay attention to the color scheme. The color scheme of the site should be easy to understand and pleasant to the user. Be sure to check your text for errors before uploading pages to the site.

Since the main task of the site is to attract visitors, the functionality should be convenient and clear so that users do not want to leave the page.

High-quality, fast-loading web-resources will attract the user's attention. It should be different in design, easy to navigate and informative in order to be popular with visitors, which affects not only the popularity of the resource, but also the reputation of its owner.

We can conclude that to create a user-friendly and functional product, you must first pay attention to its structure.

Here is the general structure of sections and subsections of the multimedia online gallery (Fig. 2). The structure is designed so that it can be easily expanded as needed.

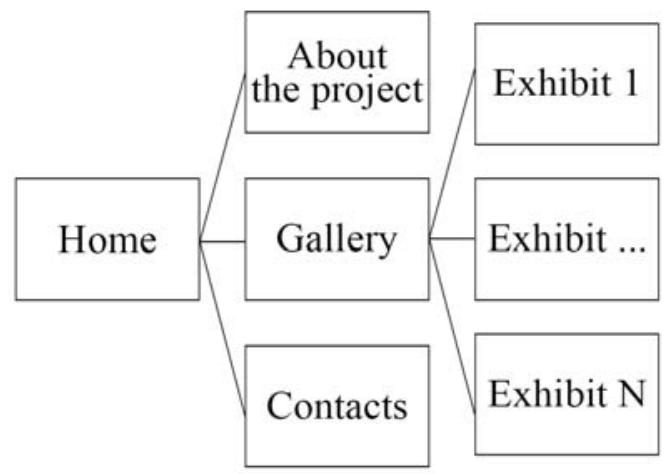

Fig. 2. The general structure of sections and subsections of the online gallery site Source: author's development.
Such electronic information products expand the boundaries of the service offered to users and serve as a basis for providing a wide range of different services.

Software methods for creating an online gallery site can be divided into two main groups.

The first group of methods for creating multimedia gallery sites includes methods for manually writing sites in one or more programming languages. Such development can be carried out both in simple text editors, and in visual editors of HTML and CSS, and the program code (it is used in the absence of sufficient level of skills in web programming).

When using this method of creating a multimedia gallery site, its graphic design is also created manually. Graphic editors are used for these purposes. It is also possible to use ready-made templates, both paid and free.

The second group of methods for creating multimedia gallery sites can include methods of automated site creation: using special site designers or content management systems (CMS - Content Management System). The most popular content management systems are Joomla and WordPress.

In addition to content management systems, there are also online designers. Designers are systems that allow you to "assemble" the site of a multimedia gallery from a ready-made standard set of modules and components and place it on the Internet. Among the most popular site designers are Wix, Weebly and uKit (uCoz).

In general, the process of creating a multimedia gallery site can be divided into 7 main stages:

1. Idea;

2. Technical task;

3. Layout;

4. HTML + CSS layout;

5. Functional programming;

6. Web hosting;

7. Promotion;

The first thing you need to decide at the stage of preparation - the coordination of the terms of reference. The project manager is usually responsible for agreeing the terms of reference in the companies involved in the development and creation of multimedia gallery sites. At this stage, the goals of the future project are agreed, the scope, functionality, structure and parameters of the visual display of the site are determined.

The second stage involves structuring the information. This is done by the multimedia gallery project manager and web designer. At this stage, the final form of the site, its content and content of this or that information. At this stage, the structure should be considered from a technical point of view. Position of blocks, presence on the site of lists and tables. A number of different points that are also determined by the project manager, for example, compiling a logical structure of the Internet resource and choosing the most profitable way 
to provide information to users (creating a table you can present the results of competitions, in the list - company preferences, in the opening blocks - answers to users).

After the terms of reference have been agreed and the information has been structured, a visual space of the future gallery site is created in the graphic editor. Existing or individually designed graphic elements are used for navigation and decoration. The appearance of a web page, which is a graphic file, is designed by a designer.

Then, using the hypertext markup language, the structure of the resource and its pages is developed. Text transfer, insertion of graphic elements, creation of tables, forms, lists is carried out by means of formation of a marking code. The process of developing the layout of a future resource is often called HTML-layout or resource layout. This code is usually created by a typesetter or programmer.

Hosting and search engine optimization of the gallery site is carried out at the final stage. Website promotion in the network allows him to rise to the top positions in search engines. Therefore, it is important to fill the site with thematic information using popular key queries. The information must be unique and useful for users.

To facilitate the process of development and successful launch of any project, it is necessary to adhere to the conditions of phasing and complexity. Ignoring one or another stage in the development of a web resource can cause problems in the further work and development of the whole project.

The initial data are the requirements for the developed system, the description of the subject area, resources and time for implementation.

After analyzing and selecting a content management system, additional extensions and components, it is advisable to proceed to planning the stages of site development.

The development process can be divided into the following stages:

1. Conceptual stage, including:

a) analysis of the target audience and study of the peculiarities of its interaction with the product, determination of the field of design and functional features of the product;

b) concept development;

c) domain and hosting selection;

2. Design stage:

a) designing the structure of sections and subsections of the site; b) designing the layout of the main page of the site;

c) designing layouts of internal pages;

3. Design stage:

a) home page design development;

b) development of design of internal pages on the basis of the developed models;

c) creating the necessary graphic elements;

4. Functional stage:

a) page layout;

b) setting the functionality of the site;

c) installation and configuration of software modules;

d) optimization of functional modules and components;

5. Testing stage:

a) hosting and setting up the site on the server;

b) site testing;

c) problem identification and refinement;

d) filling with content;

e) run under a domain name;

f) testing and error correction;

6. Operational stage:

a) registration in major search engines and directories.

\section{Conclusions}

Based on the results of the study, it can be concluded that the creation of a multimedia online gallery requires a sufficient level of knowledge and skills and is limited to the task of developing a website that should provide the necessary functionality to encourage users, access and disseminate information.

The scientific result of this article is to develop a method of creating a multimedia online gallery based on the use of appropriate CMS and key ergonomic requirements.

The practical result is a set of recommendations to developers and designers to improve the quality and efficiency of creating a multimedia online gallery.

The description and visualization of the components of the multimedia online gallery involved in the software implementation of the development should be carried out in accordance with the proposed general structure of sections and subsections of the online gallery site.

A further direction of this study may be the creation of a methodology for evaluating the effectiveness of the development of a multimedia online gallery.

\section{References}

1. Naumenko M. Elaboration of methodology for designing a publishing and printing web portal / M. Naumenko, Y. Hrabovskyi // Eastern-European Journal of Enterprise Technologies. - 2018. - № 2(92). - P. 14-22. https://doi:10.15587/1729-4061.2018.126305.

2. Martins P. Web-based Tool for Business Process Improvement / P. Martins, M. Zacarias // International Journal of Web 
Portals. - 2017. - № 9. - № 1. - P. 68-84. https://doi.org/10.4018/IJWP.2017070104.

3. Adachi Y. Malware analysis system using process-level virtualization / Y. Adachi, Y. Oyama // Proceedings of IEEE Symposium on Computers and Communications. - Sousse 5-8 July 2009. - P. 550-556.

4. Zheng J. Wireless Sensor Networks: A Networking Perspective / J. Zheng, A. Jamalipour. - Toronto: A John \& Sons, 2009. $-528 \mathrm{p}$.

5. Hryshchuk R. Synergetic control of social networking services actors' interactions / R. Hryshchuk, K. Molodetska // Recent Advances in Systems, Control and Information Technology. - 2017. - № 543. - P. 34-42. - https://doi.org/10.1007/978-3319-48923-0_5.

6. Dwivedi A. Space-Age Approach To Transmit Medical Image With Codebase Cryptosystem Over Noisy Channel / A. Dwivedi. - 2010. - № 2(12). - P. 7112-7117.

7. Raj K.G. An Authenticated Transmission of Medical Image with Codebase Cryptosystem over Noisy Channel [Electronic resource] / K.G. Raj, A. Sharma. - 2011. - No. 5(2). - P. 841-845. - Available at: https://www.researchgate.net/publication/220031760_An_Authenticated_Transmission_of_Medical_Image_with_Codebase_Cry ptosystem_over_Noisy_Channel.

8. Christal Mary S. Suma A Novel Approach For Information Security In Ad Hoc Networks Through Secure Key Management / S. Suma Christal Mary, M. PallikondaRajasekaran, Y. ChrisbinJeeva // Journal of Computer Science. - 2013. - No. 11. - P. 1556-1565. https://doi.org/10.3844/jcssp.2013.1556.1565.

9. Cloud Scale Isn't Enough [Electronic resource]. - Available at: https://www.sdxcentral.com/articles/news/forthomsonreuters-cloud-scale-isnt-enough/2016/09/.

10. Transmission of Picturesque content with Code Base Cryptosystem [Electronic resource]. - Available at: https://doaj.org/article/6714b60516cc4aa79e56d0c421 febaf3.

11. Hrabovskyi Y. Methods of Assessment and Diagnosis of the Quality of Knowledge in E-Learning / Y. Hrabovskyi // Journal of Communication and Computer. - 2015. - No. 12. - P. 286-296.

12. Hrabovskyi Y. Development of information visualization methods for use in multimedia applications. / Y. Hrabovskyi, N. Brynza, O. Vilkhivska // Physics and Engineering. - 2020. - No. 1. - P. 3-17. https://doi.org/10.21303/24614262.2020.001103.

13. The nepenthes platform: An efficient approach to collect malware / P. Baecher, M. Koetter, M. Dornseif, F. Freiling / Proceedings of the 9th International Symposium on Recent Advances in Intrusion Detection. - Berlin, September 2006. - P. 165184. - Available at: https://www.syssec.ruhr-uni-bochum.de/media/emma/veroeffentlichungen/2012/08/07/NepenthesRAID06.pdf.

14. Brambilla M. Large-scale Model-Driven Engineering of web user interaction: The WebML and WebRatio experience / M. Brambilla // Science of Computer Programming. - 2014. - No. 89. - P. 71-87. https://doi.org/10.1016/j.scico.2013.03.010.

Received by Editorial Board 29.02.2021

Signed for Printing 13.04.2021

\section{Відомості про автора:}

Грабовський Євген Миколайович

кандидат економічних наук доцент доцент кафедри Харківського національного економічного університету ім. С. Кузнеця, Харків, Україна https://orcid.org/ 0000-0001-7799-7249

\section{Information about the author:}

Yevhen Hrabovskyi

Ph.D. Associate Professor

Simon Kuznets Kharkiv National University

of Economics,

Kharkiv, Ukraine

https://orcid.org/ 0000-0001-7799-7249

\section{МЕТОДИКА СТВОРЕННЯ МУЛЬТИМЕДІЙНОЇ ОНЛАЙН-ГАЛЕРЁ̈}

\section{Є.М. Грабовський}

Метою статті є розробка методики створення мультимедійної онлайн-галереї на основі використання відповідної CMS та ключових ергономічних вимог. Практичним результатом проведеного дослідження є комплекс рекомендацій розробникам та дизайнерам стосовно підвищення якості та оперативності створення мультимедійної онлайн-галереї. Робочою гіпотезою дослідження стало твердження про те, щьо структура розділів мультимедійної онлайн-галереї може бути визначена на основі необхідних функиіональних можливостей галереї. Для перевірки робочої гіпотези дослідження було запропоновано такі наукові завдання досягнення цілей, як алгоритмізація вибору структури мультимедійної онлайн-галереї, узгодження базової множини функиій, класифікаиія функиій та розділів методом кластеризації. В роботі створено дерево цілей розробки мультимедійної онлайн-галереї. Розглянуто набір загальних вимог до сайту онлайн-галереї, щзо описують концептуальні, конструктивні та інші вимоги. Наведено та обтрунтовано загальну структуру розділів та підрозділів мультимедійної онлайн-галереї. Детально проаналізовані програмні методи створення сайту онлайн-галереї. В статті систематизовано основні системи управління контентом та онлайн-конструктори, які дозволяють з готового типового набору модулів і компонентів “зібрати” сайт електронної галереї і розмістити його в Інтернеті. Окрема увага в роботі приділена етапам узгодження технічного завдання та структурування інфо- 
рмаиії. Акцентовано увагу на питаннях пошукової оптимізаиії сайту галереї з метою підвищення індексації у відповідних системах. В роботі наведено чіткий розподіл функиій менеджера проекту мультимедійної галереї та вебдизайнера стосовно розробки сайту галереї та його просування в пошукових системах. В статті описані необхідні вихідні дані до розробки мультимедійної онлайн-галереї, у якості яких є вимоги до розроблюваної системи, опис предметної області, ресурси та час на реалізачію. У дослідженні наведено перелік ключових етапів створення мультимедійної онлайн-галереї та проаналізовано основні складові елементи ичих етапів. В статті рекомендовано здійснювати опис та візуалізацію компонентів мультимедійної онлайн-галереї, задіяних в прочесі програмної реалізачії розробки, відповідно до запропонованої загальної структури розділів та підрозділів сайту онлайн-галереї. У якості подальшого напрямку даного дослідження пропонується вважати створення методики оиінки ефективності розробки мультимедійної онлайн-галереї.

Ключові слова: онлайн-галерея, візуалізачія, дизайн, цільова аудиторія, ергономічні вимоги.

\section{МЕТОДИКА СОЗДАНИЯ МУЛЬТИМЕДИЙНОЙ ОНЛАЙН-ГАЛЕРЕИ}

Е.Н. Грабовский

Целью статьи является разработка методики создания мультимедийной онлайн-галереи на основе использования соответствующей CMS и ключевых эргономических требований. Практическим результатом проведенного исследования является комплекс рекомендаций разработчикам и дизайнерам по повышению качества и оперативности создания мультимедийной онлайн-галереи. Рабочей гипотезой исследования стало утверждение о том, что структура разделов мультимедийной онлайн-галереи может быть определена на основе необходимых функииональных возможностей галереи. Для проверки рабочей гипотезы исследования было предложено следуюшие задачи достижения целей, как алгоритмизация выбора структуры мультимедийной онлайн-галереи, согласование базового множества функций, классификация функций и разделов методом кластеризации. В работе создано дерево целей разработки мультимедийной онлайн-галереи. Рассмотрены набор общих требований к сайту онлайн-галереи, описываютих концептуальные, конструктивные и другие требования. Приведено и обосновано общую структуру разделов и подразделов мультимедийной онлайн-галереи. Подробно проанализированы программные методы создания сайта онлайн-галереи. В статье систематизированы основные системы управления контентом и онлайн-конструкторы, которые позволяют с готового типового набора модулей и компонентов “собрать” сайт электронной галереи и разместить его в Интернете. Особое внимание в работе уделено этапам согласования технического задания и структурирования информации. Акиентировано внимание на вопросах поисковой оптимизащии сайта галереи с целью повышения индексации в соответствующих системах. В работе приведены четкое распределение функиий менеджера проекта мультимедийной галереи и вебдизайнера по разработке сайта галереи и его продвижение в поисковых системах. В статье описаны необходимые исходные данные к разработке мультимедийной онлайн-галереи, в качестве которых выступают требования к разрабатываемой системе, описание предметной области, ресурсы и время на реализацию. В исследовании приведен перечень ключевых этапов создания мультимедийной онлайн-галереи и проанализированы основные составляющие элементы этих этапов. В статье рекомендуется осуществлять описание и визуализацию компонентов мультимедийной онлайн-галереи, задействованных в процессе программной реализации разработки, в соответствии с предложенной общей структурой разделов и подразделов сайта онлайн-галереи. В качестве дальнейшего направления данного исследования предлагается считать создание методики оценки эффективности разработки мультимедийной онлайн-галереи.

Ключевые слова: онлайн-галерея, визуализация, дизайн, целевая аудитория, эргономические требования. 